\title{
Women experiencing the intergenerationality of conjugal violence ${ }^{1}$
}

\author{
Gilvânia Patrícia do Nascimento Paixão² \\ Nadirlene Pereira Gomes ${ }^{3}$ \\ Normélia Maria Freire Diniz ${ }^{3}$ \\ Margaret Ollinda de Souza Carvalho e Lira ${ }^{4}$ \\ Milca Ramaiane da Silva Carvalho² \\ Rudval Souza da Silva ${ }^{5}$
}

Objective: to analyze the family relationship, in childhood and adolescence, of women who experience conjugal violence. Method: qualitative study. Interviews were held with 19 women, who were experiencing conjugal violence, and who were resident in a community in Salvador, Bahia, Brazil. The project was approved by the Research Ethics Committee (N. 42/2011). Results: the data was organized using the Discourse of the Collective Subject, identifying the summary central ideas: they witnessed violence between their parents; they suffered repercussions from the violence between their parents: they were angry about the mother's submission to her partner; and they reproduced the conjugal violence. The discourse showed that the women witnessed, in childhood and adolescence, violence between their parents, and were injured both physically and psychologically. As a result of the mother's submission, feelings of anger arose in the children. However, in the adult phase of their own lives, they noticed that their conjugal life resembled that of their parents, reproducing the violence. Conclusion: investment is necessary in strategies designed to break inter-generational violence, and the health professionals are important in this process, as it is a phenomenon with repercussions in health. Because they work in the Family Health Strategy, which focuses on the prevention of harm and illness, health promotion and interdepartmentality, the nurses are essential in the process of preventing and confronting this phenomenon.

Descriptors: Family Conflict; Domestic Violence; Violence Against Women; Health Spenditures; Intergenerational Relations; Reproduction.

\footnotetext{
${ }^{1}$ Paper extracted from master's thesis "Marital violence: understanding the phenomenon from the female discourse", presented to Escola de Enfermagem, Universidade Federal da Bahia, Salvador, BA, Brazil.

2 Doctoral student, Escola de Enfermagem, Universidade Federal da Bahia, Salvador, BA, Brazil. Assistant Professor, Faculdade de Enfermagem, Universidade do Estado da Bahia, Senhor do Bonfim, BA, Brazil.

3 PhD, Professor, Escola de Enfermagem, Universidade Federal da Bahia, Salvador, BA, Brazil.

${ }^{4}$ Doctoral student, Escola de Enfermagem, Universidade Federal da Bahia, Salvador, BA, Brazil. Assistant Professor, Faculdade de Enfermagem, Fundação Universidade do Vale do São Francisco, Petrolina, PE, Brazil.

${ }^{5}$ Doctoral student, Escola de Enfermagem, Universidade Federal da Bahia, Salvador, BA, Brazil. Assistant Professor, Faculdade de Enfermagem, Universidade do Estado da Bahia, Senhor do Bonfim, BA, Brazil. Scholarship holder from Coordenação de Aperfeiçoamento de Pessoal de Nível Superior (CAPES), Brazil.
}

Corresponding Author:

Gilvânia Patrícia do Nascimento Paixão

Universidade do Estado da Bahia. Colegiado de Enfermagem Campus VII

Rod. Lomanto Júnior, BR 407, km 127

Zona Rural

CEP: 48700-000, Senhor do Bonfim, BA, Brasil

E-mail: gilvania.paixao@gmail.com
Copyright @ 2015 Revista Latino-Americana de Enfermagem This is an Open Access article distributed under the terms of the Creative Commons Attribution Non-Commercial License (CC BY-NC).

This license lets others distribute, remix, tweak, and build upon your work non-commercially, and although their new works must also acknowledge you and be non-commercial, they don't have to license their derivative works on the same terms. 


\section{Introduction}

Violence against women is a multicausal phenomenon, which has as a common factor the naturalization of gender inequalities. Brazil recorded 16.9 thousand deaths of women due to gender conflict between 2009 and 2011, particularly in cases of aggression perpetrated by intimate partners, there being a rate of 5.8 cases per 100,000 women, this rate increasing to 6.9 in the Northeast of Brazil(1).

In relation to the impacts, approximately $35 \%$ of the complaints made by women in the health services are related to some type of aggression(2). As a result of this, public costs in Brazil, in 2004, revealed that the health sector spent 804 million reais on the treatment of patients with Arterial Hypertension; approximately 90.2 billion reais were spent as a result of violence, which includes prevention, treatment, and rehabilitation of the victims. This is equivalent to a cost of $5 \%$ of GDP (Gross Domestic Product), demonstrating, in this way, that violence has major financial repercussions(3).

One study undertaken indicates that the domestic environment is a central space for the ill-treatment of women, the partner being the main aggressor(4), this characterizing conjugal violence, which is defined as any act which results or may result in harm or physical, sexual or psychological suffering, committed by men or women against the person with whom they have an intimate relationship ${ }^{(5)}$. It is emphasized that this definition is not limited to legally-established relationships, neither to the sex of the victim or perpetrator, as it encompasses homo-affective relationships.

Conjugal violence occurs cyclically and repetitively, and intensifies over time(6). One study undertaken based on attendances based on calls to helplines revealed that in $38 \%$ of the cases the relationship with the aggressor was more than 10 years old(7). It may also be observed that in spite of the many years of living with violence, many women continue in the relationship.

The reasons for remaining in the conflictual relationship are anchored in the idea that the woman owes obedience to the man, above all to the spouse, causing many to experience conjugal violence passively throughout their lives. The woman acts in conformity with the socially-constructed value systems, which guide and influence the way of signifying and understanding the phenomenon, such that the woman does not identify herself as an oppressed person, impeding her from perceiving that she is experiencing violence ${ }^{(8)}$.
The naturalization of gender inequalities is grounded in the dichotomy between female and male, historically based in the anatomical-physiological differences, which express principles of vision and division of the subjects: woman/ inferior, frail and passive and man/superior, strong and active. In the intrafamily relationship, these dichotomous standards are assimilated, reproduced, and legitimated ${ }^{(9)}$.

As if the internalization of gender inequality were not enough, the conjugal violence witnessed by the children tends to be reproduced. This occurs due to the mechanism of internalization, which functions as a form of identification/similarity based in the behaviors and values learned, which are naturalized between the different social groups ${ }^{(9)}$. This context shows the extent to which coexistence in a violent environment conditions people to repeat the same practices. Thus, as a result of the absence of other models of family relationships, men and women tend to reproduce the history of violence which they experienced in childhood or adolescence ${ }^{(10-11)}$.

Based on the premise that there is an association between the experiencing of violence between family members during childhood/adolescence, mainly when it occurs between the parents, in the conjugal relationship, this study aimed to analyze the family relationship, in childhood and adolescence, of women experiencing conjugal violence.

\section{Method}

This study has a qualitative approach, of the strategic social type, as it is based in the theories of the social sciences; however, its main objective is to clarify specified aspects of the context for the action of public policies ${ }^{(12)}$. The study was undertaken in the city of Salvador (Bahia, Brazil), in a community which is characterized by low socio-economic indicators. There is, in this community, an association which offers support to the residents, promoting spaces for entertainment, education and health. This entity was created in 1992, proposing a space in which women could discuss the problems related to their everyday life, principally in relation to domestic violence, as this was a form of harm present in the life of the first members, leading them to increasing their knowledge in the issue of women's rights such that they may leave the situation.

A total of 19 women contributed to the study, who met the inclusion criteria: to be older than 18 years old, to live in the community, and for there to be a history of violence in the conjugal relationship. The contact with the contributors took place due to the support of the abovementioned association, which made it possible for the 
researcher and the women to develop a relationship, and for the former to select possible contributors to the study.

This study complied with Resolution 196/96 of the Brazilian Health Council, the project being registered under 42/2011 of the Research Ethics Committee of the School of Nursing of the Federal University of Bahia (UFBA). In this regard, the ethical precepts in the study were guaranteed, such as the right to decide regarding participating and withdrawing at any stage. The confidentiality of the information and the absence of any financial benefits was explained to the contributors. Upon accepting to participate in the study, the contributors signed the Terms of Free and Informed Consent.

Data collection took place in a room belonging to the association, at a prearranged time agreed with the contributors, being implemented based on an interview and led by the guiding question: "Tell us about your parents' conjugal experience in your childhood". Data collection took place between March and May 2012, and the interviews lasted from 25 to 55 minutes.

The accounts were transcribed after the interview, and were organized in accordance with the methodological strategy of the Discourse of the Collective Subject (DCS), this being a technique found for recovering the collective discourse in individual discourses. In this method, the collective thinking is not linked to the sum of the individual thoughts (percentage numerical representation), but to the discourse of the collectivity, the social imaginary, social representations and pre-existing thinking. The proposal of DCS aims, above all, to make the appropriate correlations that the collectivity brings in its discourse, and which carry the intrinsic values, which belong to that specific culture, present in the routine of the social subjects(13).

In order to faithfully follow the method, some stages were undertaken, referred to below: undertaking of the transcription of the accounts, resulting from the interview; analysis of the verbal material collected, extracting from each one of the oral accounts the following methodological figures: Central Ideas (CI) and their respective Key Expressions (KE); based on the $\mathrm{CI}$ and $\mathrm{KE}$, the various summary-discourses were structured, termed DCS(13). The analysis of the data was based on the issues of domestic violence, gender relationships, and intergenerational violence.

\section{Results}

The contributors are characterized as belonging to the age range between 19 and 58 years old, being black, and having a low educational level.
The individual interviews were organized in four summary central ideas, which allowed a better understanding regarding the childhood and adolescence of the women experiencing conjugal violence, namely: they witnessed violence between their parents; they suffer the repercussions of the violence between their parents; they were angered by the mother's submission to the partner; and they reproduced the conjugal violence.

\section{Summary central idea 1 - Witnessing violence between the parents}

In this central idea, one can perceive that the women who live in a conjugal relationship permeated by violence witnessed, when children, violence between their parents, as made clear in the following discourse: When mommy lived with him, she suffered a lot. It was a horrible suffering. They lived in a state of violence. He got the things from the house and sold them, he treated her badly, he didn't respect her, he brought women into the house to use drugs and to have sex with, and mom didn't say a word. He wanted to hit her, he was always shouting at her, saying he was going to hit her, that psychological pressure. My father was always authoritarian, he believed that it was right for men to push women around, prejudiced, jealous. He dominated my mother. My father spent a lot of time far from home, because his job involved traveling. My mother never worked outside the house, because he didn't want that and wouldn't let her. They argued a lot because of jealousy, lack of money, and use of alcohol. He was possessive, and wouldn't even let her leave the house to go to my grandmother's house. My mother was a fighter, and brought up her children, all six of us, practically on her own, because my father's money was for gambling, drinks, and prostitutes. Sometimes my mother tried to get money for buying food and couldn't get any, because he spent it all on the street. When he wasn't around, she used to wash clothes for other people, and did cleaning, without him knowing, and it was with this money that we ate [...] and in addition to all that, she would come home and get hit by him. She became ill [...]. Even now, he carries the guilt of having let drink take control of his life and destroy our family. (Discourse of the Collective Subject 1)

\section{Summary central idea 2 - Suffering the repercussions of the violence between the parents}

In this collective discourse, it is evidenced that the conjugal violence brings repercussions for the children, revealing that the aggression is not limited only to the female partner: [...] When they argued, it ended up spreading to me and my brothers and sisters. When we became 
adolescents, and they argued, and we tried to intervene, he [the father] began to insult us with offensive names like slut, thief, etc. He locked us in the house and wouldn't let us go out. I even have a scar, even now, because of one of their fights, one of them threw the ashtray and it hit me, here [forehead]. Another time, I intervened in one of their fights and got punched in the face. (Discourse of the Collective Subject 2).

\section{Summary central idea 3 - They were angered by the mother's submission to the partner}

In this central idea, it is emphasized that the female subjection to the mistreatment from the partner is not understood by the children, causing anger on the part of these. She (the mother) always accepts everything that he does. All this led to a certain anger among us [the children]. She was his prisoner, and never had the courage to stand up to him, to make a complaint to the police. I went and complained to the police one time that he hit us, and she didn't go, and I was furious with her because of this. (Discourse of the Collective Subject 3)

\section{Summary central idea 4 - Reproducing the conjugal violence}

In this discourse, it is possible to note that the women interviewed understand that they are experiencing disrespectful relationships with their partners, which resemble what they witnessed in their childhood and adolescence, between their parents. What's worse is that everybody says that I am following the same path as my mother. My life is turning out just like my mother's, because the same as happened with her is happening with me: a troubled relationship, everything is identical, as if I were carrying her karma, beaten like my mother was (Discourse of the Collective Subject 4).

\section{Discussion}

The discourse of the women experiencing situations of conjugal violence reveals that these - in their childhood and adolescence - witnessed violence between their parents, their mothers having experienced physical, psychological, moral and patrimonial aggression.

In a relationship permeated by conjugal violence, there is an unequal power relationship between man and woman, in which the man, upon feeling threatened, and in order to reestablish the power which he believes he has over the woman, uses disrespectful means to control his partner, this including physical force ${ }^{(14)}$. Addressing violence against the woman involves, as well as the legal and punitive aspect, reflection regarding the gender roles, which are socially constructed and legitimated, including by the women themselves. This promotes and reinforces the sexist ideology and androcentric vision of the world(15).

This understanding shows the dimension of the complexity of this phenomenon and facilitates understanding regarding women's remaining in the conjugal relationship. The discourse reveals that the participants, during childhood and adolescence, due to not understanding their mother's subjection to the partner, became angry with them. This idea of the woman's submission to the man is reinforced by various authors ${ }^{(16)}$, revealing that for nearly half of the interviewees, domestic violence occurs for a cultural reason, being anchored in machismo, justifying the belief that the man is the owner of the woman. This finding explains the legitimation of male supremacy, expressed through the oppression of the female by the male, favoring the occurrence of conjugal violence.

Emphasis is placed on the impossibility of isolating any one of the members of the family from the impact of the violence. Coexistence in the family ambit permeated by the conjugal violence, therefore, brings serious harm to the couple, above all to the woman, with repercussions for the children ${ }^{(17)}$. According to the discourse, the women who are currently experiencing a relationship permeated by violence witnessed this phenomenon between their parents when children themselves.

Among the different forms taken by violence, children/adolescents are more vulnerable to suffering from domestic violence, the fathers being the main culprits $^{(18)}$. Domestic violence against the child/ adolescent causes serious physical and psychological harm, which is often irreversible, or death. In this context, for some authors, the death of many children results from violence in the "home"(19).

Data on violence against women show that in more than $65 \%$ of cases, the children witness the aggression committed against their mothers, and are also victims of violence in approximately $20 \%{ }^{(20)}$. When the children experience their mothers being the victims of violence, they are often victims as well, their physical, social and psychological health being compromised, this being related to nightmares, poor self-esteem, anxiety and depression among other psychological disorders, which may be expressed through poor school performance, an increase in the rates of dropping out of school, repeating school years, and poor behavior ${ }^{(21)}$.

One can note, therefore, that witnessing the mother suffering any type of violence is a factor for vulnerability 
for the children, such that these children have higher chances of experiencing it when adults, either as victims in the case of the women - or as aggressors, in the case of the men(17). As a result, academics agree that experiencing violence in childhood and adolescence has repercussions for the individuals' adult lives, acting similarly with sisters, school friends, and - in the future girlfriends and wives/partners(22).

The collective discourse shows that the women perceive that they are experiencing with their partners situations which their mothers experienced, drawing attention to the intergenerational character of conjugal violence which, in its turn, is characterized by the historical reproduction of the violence experienced in childhood and/or adolescence. This reproduction occurs due to the mechanism of internalization, which functions as a form of identification/similarity, based on the behaviors and values learned, which are naturalized among the different social groups, in this case the family ${ }^{(9)}$. This context shows the extent to which coexisting in a violent environment conditions people to repeat the same practices, as, where other models of family relationships were not learned, men and women tend to reproduce the history of violence which they experienced in childhood or adolescence ${ }^{(10)}$.

Various studies have demonstrated the intergenerational character of conjugal violence, both for the aggressor and the victim. The chance of the practicing of violence increases by $96 \%$, should the mother of the male partner have been the victim of violence by her partner (the son's father/stepfather) during his childhood. The chance of suffering violence was $92 \%$ greater in women whose mothers had also been victimized(23). One longitudinal study, spanning three generations, revealed that if the grandmother was abused by her husband, the daughter is more susceptible to be sexually molested in childhood. Similarly, should the mother have been sexually abused when a child, her daughter has a greater risk of suffering child sexual abuse. In their turn, abused daughters express great anxiety in relation to romantic relationships, as well as conflicts of precocious fixation (24). It follows that people with a history of abuse in childhood, who witnessed conjugal violence from their fathers, have higher chances of experiencing violence in their conjugal relationships ${ }^{(25)}$.

Hence, the intergenerational transmission of violence has been used to explain the relationship between violence witnessed in the family of origin and violence practiced by the intimate partner. In the light of this context, it is essential that professionals from the fields of health and education should be alert to recognize children and/or adolescents who are vulnerable to, or experiencing, domestic violence, so as to be able to adopt strategies for preventing intergenerational violence.

\section{Conclusion}

The interviewees who experience violence in the conjugal relationship witnessed violence between their parents in childhood and adolescence, and suffered the repercussions of this violence, being physically injured, slandered and vilified, among other forms of violence practiced by the fathers. In the light of this experience, the interviewees stated feelings of anger, because of the fact that the mother had adopted an attitude of submission to the partner. In the adult phase, they understand that their conjugal life resembles the life of their parents: they have reproduced the conjugal violence.

The study points to the need for investment in strategies for breaking the cycle of intergenerational violence, reaffirming the complexity of the phenomenon and the importance of social work undertaken with the community, so as to promote families' health. As it leads to a continuous and progressive process of loss of health, with serious repercussions not only for the woman, but also for the family - above all the children health professionals have great importance in this process, as it is a phenomenon which causes serious harm to the health of all those involved.

The professionals who work in the Family Health Strategy are in an outstanding position, as primary healthcare has, as its leading axes, the prevention of harm to health and illnesses, the promotion of health, and interdepartmentality. Nurses, as members of specialist teams in the municipalities and, often, having management positions, both in the health centers and in the specialized areas, must be prepared to elaborate, encourage and viabilize actions for preventing violence in the ambit of the community, demanding actions which are articulated with other levels of healthcare, in conjunction with other areas (the law, the social services, the police, education etc).

Articulation between the health sector and other spheres - such as education and the social services is also essential in order for there to be reflection upon and elaboration of projects and actions which promote the identification of children and adolescents experiencing domestic violence, so as to break, at 
the earliest stage possible, the cycle of violence: intergenerational violence.

\section{References}

1. Minne J, Chalamet M, Gabriel MAO, Carneiro RS, Teixeira A. Uma análise socioeconômica das mulheres da Praça da Bandeira. Rev Conexões Psi. 2014;2(1):84108.

2. Domingues $B$, Machado $K$. Às vítimas de violência sexual, atendimento humanizado. Radis Comun Saúde. 2011;(92):10-5.

3. Silva M. Conferência Nacional de Saúde Mental. Violência: um problema de saúde pública. Ministério da Saúde. Brasília; 2010. 6 p.

4. Gomes NP, Silveira YM, Diniz NMF, Paixão GPN, Camargo CL, Gomes NR. Identificação da violência na relação conjugal a partir da estratégia saúde da família1. Texto Contexto Enferm. 2013;22(3):789-96.

5. Miranda MPM, Paula CS, Bordin IA. Violência conjugal física contra a mulher na vida: prevalência e impacto imediato na saúde, trabalho e família. Rev Panam Salud Publica. 2010;27(40):300-8.

6. Paixão GPN, Gomes NP, Diniz NMF, Couto TM, Vianna LAC, Santos SMP. Situations which precipitate conflicts in the conjugal relationship: the women's discourse. Texto Contexto Enferm. 2014;23(4):1041-9.

7. Secretaria de Políticas Para as Mulheres (BR). Balanço central de Atendimento à Mulher. Brasília (DF): Secretaria de Políticas Para as Mulheres; 2010.

8. Passos MD, Gugelmin SÂ, Castro IR, Carvalho MC. Social representations of the body: a study of adolescents in the city of Rio de Janeiro, Brazil. Cad Saúde Pública. 2013;29(12):2383-93.

9. Tondowski CS, Feijó MR, Silva EA, Gebara CF, Sanchez ZM, Noto AR. Padrões Intergeracionais de Violência Familiar Associada ao Abuso de Bebidas Alcoólicas: Um Estudo Baseado em Genogramas. Psicologia: Reflexão e Crítica. 2014;27(4):806-14.

10. Gomes NP, Diniz NMF, Araújo AJS, Coelho TMF. Compreendendo a violência doméstica a partir das categorias gênero e geração. Acta Paul Enferm. 2007;20(4):504-8.

11. Lima GQ, Werlang BSG. Mulheres que sofrem violência doméstica: contribuições da psicanálise. Psicol Estud. 2011;16(4):511-20.

12. Minayo MCS. Análise qualitativa: teoria, passos e fidedignidade. Cienc Saúde Coletiva. 2012;17(3):621-6. 13. Figueredo MA, Chiari BM, Goulart BNG. Discurso do sujeito coletivo: uma breve introdução à ferramenta de pesquisa qualiquantitativa. Disturb Comum. 2013; 25(1):129-36.

14. Gomes NP, Diniz NMF. Homens desvelando as formas de violência conjugal. Acta Paul Enferm. 2008;21(2):262-7.

15. Bourdieu P. A dominação masculina. 4ed. Rio de Janeiro: Bertrand; 2005. 160 p.

16. Santos CM, Izumino WP. Violência contra as Mulheres e Violência de Gênero: Notas sobre Estudos Feministas no Brasil. Estudios Interdisciplinarios de América Latina y el Caribe. 2014; 16(1): 151-9.

17. Durand JG, Schraiber LB; França-Junior I, Barros C. Repercussão da exposição à violência por parceiro intimo no comportamento dos filhos. Rev de Saúde Pública. 2011;45(2):355-64.

18. Vieira LJES, Ferreira RC, Moreira GAR, Gondim APS, Araujo MAL, Silva RM. Factors associated to the imposition of types of violence against women informed in sentry services. Rev. Latino-Am. Enfermagem. 2013;21(4):920-7.

19. Bannwart TH, Brino RF. Dificuldades enfrentadas para identificar e notificar casos de maus-tratos contra criança e/ou adolescente sob a óptica de médicos pediatras. Rev Paul Pedriatr. 2011;29(2):138-45.

20. Secretaria de Políticas para Mulheres (BR). Balanço semestral do ligue 180 (janeiro à junho/2012). Brasília: Secretaria de Políticas para as Mulheres; 2012. 16 p.

21. Ludermir AB, Lewis G, Valongueiro SA, Araujo TV, Araya $R$. Violence against women by their intimate partner during pregnancy and postnatal depression: a prospective cohort study. Lancet. 2010;376:903-10.

22. Labronici LM, Ferraz MIR, Trigueiro TH, Fegadoli D. Perfil da violência contra mulheres atendidas na Pousada de Maria. Rev Esc Enferm USP. 2010;44(1):126-33.

23. Vieira EM, Perdona GSC, Santos MA. Fatores associados a violência física por parceiro íntimo em usuárias de serviço de saúde. Rev Saúde Pública. 2011;45(4):730-7.

24. Mccloskey LA. [A transferência intergeracional de risco de mãe e filha por abuso de gênero]. Psychodyn Psychiatry. 2013;41(2):303-28.

25. Zaleski M, Pinsky I, Laranjeira R, Ramisetty-Mikler S, Caetano R. [Violência íntima por parceiro e a contribuição do consumo alcóolico características sociodemográficas: a Pesquisa Nacional do Álcool brasileiro]. J Interpers Violence. 2010;25(4):648-65. 